\section{SENSITIVE SPECTROPHOTOMETRIC \\ DETERMINATION OF LAMOTRIGINE IN BULK DRUG AND PHARMACEUTICAL FORMULATIONS USING BROMOCRESOL GREEN}

N. Rajendraprasad, K. Basavaiah* ${ }^{*}$ and K. B. Vinay

\author{
Department of Chemistry, University of Mysore, Manasagangothri, Mysore-570 006, India
}

"Corresponding e-mail: basavaiahk@yahoo.co.in. Mobile: +91-9448939105
Fax: 0091-821-2421263, 2516133. \begin{abstract}
Two new, simple, rapid and reproducible spectrophotometric methods have been de-
veloped for the determination of lamotrigine (LMT) both in pure form and in its tablets. The first method (method A) is based on the formation of a colored ion-pair complex $(1: 1 \mathrm{drug} /$ dye $)$ of LMT with bromocresol green (BCG) at $\mathrm{pH} 5.02 \pm 0.01$ and extraction of the complex into dichloromethane followed by the measurement of the yellow ion-pair complex at $410 \mathrm{~nm}$. In the second (method B), the drug-dye ion-pair complex was dissolved in ethanolic potassium hydroxide and the resulting base form of the dye was measured at $620 \mathrm{~nm}$. Beer's law was obeyed in the concentration range of 1.5-15 $\mu \mathrm{g} \mathrm{mL}^{-1}$ and $0.5-5.0 \mu \mathrm{g} \mathrm{mL}^{-1}$ for method A and method B, respectively, and the corresponding molar absorptivity values are $1.6932 \times 10^{4}$ and $3.748 \times 10^{4}$ $\mathrm{L} \mathrm{mol}{ }^{-1} \mathrm{~cm}^{-1}$. The Sandell sensitivity values are 0.0151 and $0.0068 \mathrm{\mu g} \mathrm{cm}^{-2}$ for method $\mathrm{A}$ and method $\mathrm{B}$. The Sacly. The stoichiometry of the ion-pair complex formed between the method $B$, respectively and dye (1.1) was determined by Job's continuous variations method and the stability constant of the complex was also calculated. The proposed methods were applied successfully for the determination of drug in commercial tablets.
\end{abstract}

Keywords: lamotrigine; spectrophotometry; ion-pair complex; bromocresol green; pharmaceuticals

\section{Introduction}

\section{Lamotrigine,}

henyl)-1,2,4-triazine-3,5ne], is an antico it has been used successfully to treat epilepsy and bipolar disorder as monotherapy and as an adjunct with other antiepileptics for treatment of partial and generalized toxic-chronic seizures. It is also used to treat neurological lesions and as a tranquilizer $[1,2]$.

Lamotrigine is not official in any pharmacopoeia. The analysis of LMT in biological samples is abundantly described in the literature. Chromatographic techniques have been widely employed since they are powerful separation techniques. The methods based on the high-performance liquid chromatography (HPLC) [3-10] high-performance thin layer chromatography (HPTLC) [11] and gas-chromatography (GC) [12] have been described. There is an extensive literature on the determination of lamotrigine in literature on the determination of lamotrigine in pharmaceuticals include planar chromatography capillary electrophoresis $[16,17]$. The immunoassay techniques $[18,19]$ have been developed for 
the determination of this drug in biological samples. UV-spectrophotometric method [20] was used for determination of LMT in tablets, where the tablet extract in $0.1 \mathrm{M} \mathrm{NaOH}$ was measured at $305 \mathrm{~nm}$. Youssef al Ta [14] have reported the application of application of the technique for the determination of LMT using chloranilic acid as a chromogen. The reported method is less sensitive with a linear range $10-200 \mu \mathrm{g} \mathrm{mL}^{-1}$ and the molar absorptivity of $1.28 \times 10^{3} \mathrm{~L} \mathrm{~mol}^{-1} \mathrm{~cm}^{-1}$. Though the method is claimed to be selective, any $\mathrm{N}$-containing basic moiety would definitely interfere with the assay.

Many of the other reported methods [1317] are sensitive and selective but they are time consuming, require expensive instrumental setup, and some requre preliminery sapte treatur, Adsorpive stipping voltametic Adsolive stipping volis highly complicated and is repoted to be less precise (RSD $\sim 10 \%$ ). Considering these drawbacks, there was a need to develop more advantageous spectrophotometric method for its determination in bulk powder and commercial dosage forms. Although many analytical methods were reported to analyze LMT in biological samples and pharmaceutical samples, none of these methods was suitable for routine analysis of LMT in pharmaceutical prepation. Extractive spectophotometic tical preparation. Extractive procedures are popular for their sensitivity in the assay of drugs and, therefore, in-pair extractive spectrophotometry has received considerable attention for the quantitative determination of many pharmaceutical compounds [22-25] and different alkaloids [26, 27].

We, therefore, developed two higly sensitive, selective, reproducible and economical spectrophotometric methods for the determination of LMT in bulk powder and in tablets by exploiting its basic nature and its ability to form ion-p its basic nathe and complex with an anionic dye bromocresol green. The first method (method A) is based on the formation of an ion-pair complex between drug and dye at $\mathrm{pH} 5.02 \pm 0.01$ followed by extraction of the complex into dichloromethane (DCM), and the yellow drug-dye complex was measured at 410 $\mathrm{nm}$. In the second method (method B), the drugdye ion-pair was broken in ethanolic alkali and the blue color of base form of the dye was measured at $620 \mathrm{~nm}$. The method B is a highly sensitive

approach for determination of LMT in bulk drug and in tablets.

Experimental

\section{Apparatus}

A Systronic model 106 digital spectrophoometer equipped with $1 \mathrm{~cm}$ quartz cells was used for absorbance measurements. A digital $\mathrm{pH}$ meter Model Elico L1 120 was used for $\mathrm{pH}$ measure-

All chemicals used were of analytical grade. Solvents used were of the spectroscopic grade. Distilled water was used through out the investigation.

Sulphuric acid (0.1 M): Concentrated acid S.D. Fine Chem, Mumbai, India, sp. gr. 1.84) was appropriately diluted with water to get $0.1 \mathrm{M}$ acid.

Bromocresol green (0.4\%): Dissolved 400 $\mathrm{mg}$ of the dye (S.D.Fine Chem Ltd, Mumbai, India) in $10 \mathrm{ml}$ of ethanol and diluted to $100 \mathrm{ml}$ with water.

Sodium acetate (1 M): Prepared by dissolving $13.61 \mathrm{~g}$ of the pure sodium acetate (Merck Specialities Pvt Ltd, Mumbai, India) in $100 \mathrm{ml}$ water.

Buffer solution ( $p H 5.02$ ): Mixed $50 \mathrm{ml}$ of $\mathrm{M}$ sodium acetate and $15 \mathrm{ml}$ of $1 \mathrm{M}$ hydrochloric acid (Merck Specialities Pvt Ltd, Mumbai, India, Sp, gr. 1.18) and volume was made upto 250 $\mathrm{ml}$, and $\mathrm{pH}$ was adjusted to 5.02 by using dilute $\mathrm{NaOAc} / \mathrm{HCl}$ solution

Ethanolic $\mathrm{KOH}(1 \%)$ : One gram of the pure $\mathrm{KOH}$ (S.D.Fine Chem Ltd, Mumbai, India) was dissolved in and diluted to $100 \mathrm{ml}$ with ethanol.

Standard drug solution $\left(30 \mu \mathrm{g} \mathrm{mL}^{-1}\right)$ : LMT (pharmaceutical grade, $99.88 \%$ pure) was procured from Cipla India Ltd, Mumbai, India, as a gift and was used as received. A stock standard solution of lamotrigine $\left(300 \mu \mathrm{g} \mathrm{mL}^{-1}\right)$ was first prepared by dissolving $30 \mathrm{mg} \mathrm{LMT} \mathrm{in} 0.1 \mathrm{M} \mathrm{H}_{2} \mathrm{SO}_{4}$ and diluting to $100 \mathrm{ml}$ in calibrated flask with the same acid. Stock solution was diluted with the same acid to get a working solution of $30 \mu \mathrm{g} \mathrm{mL}$

Lamosyn 100 and lamosyn 25 (both from Sun Pharmaceuticals Ltd, Mumbai, India) and Lametec 50-DT (Cipla India Ltd, Mumbai, India)all tablets were purbased from local mater were used in the investigation.

\section{Recommended Procedures}

Method A

Into a series of $125 \mathrm{ml}$ separating funnels, aliquots of lamotrigine standard solution $(30 \mu$ $\mathrm{mL}^{-1}$ ) equivalent to $1.5-15.0 \mu \mathrm{g} \mathrm{mL}^{-1} \mathrm{LMT}$ were accurately transferred and the total volume was brought to $5 \mathrm{ml}$ by adding $0.1 \mathrm{M} \mathrm{H} \mathrm{SO}_{\text {to }}$ to each funnel. funnel. To each $\mathrm{M} \mathrm{NaOAC}$ and $5 \mathrm{ml}$ bufer of $\mathrm{pH}$ 5.02 followed by 5 m d dye $(0.4 \%)$, and of $\mathrm{pH}$ 5.02 followed by $5 \mathrm{ml}$ dye $(0.4 \%)$, and the conent was mixed well. The funnels were shaken vigorously with $10 \mathrm{ml}$ of dichloromethane (added from microburette) for 30 seconds, and then allowed to stand for clear separation of the two phases. The separated organic layer was passed ove anhydrous sodium sulphate and absorbance of the yellow ion-pair complex was measured at $410 \mathrm{~nm}$ against a reagent blank similarly prepared.

\section{Method B}

Varying aliquots of LMT-BCG ion-pair complex (10 $\mathrm{g} \mathrm{mL}^{-1}$ in LMT; prepared by following the procedure described in method $\mathrm{A}$ ) equivalent to $0.5-5.0 \mu \mathrm{g} \mathrm{mL}^{-1}$ with respect to $\mathrm{LMT}$ were transferred into a series of $10 \mathrm{~mL}$ standard flasks and the total volume was brought to $5 \mathrm{~mL}$ by adding dichloromethane. To each flask, $1 \mathrm{~mL}$ of $1 \%$ alcohlic $\mathrm{KOH}$ was added, the content mixed $1 \%$ alcoholic KOH was added, he content mixed and kept aside for 5 mas made upto mark with ethanol and the absorbance measured at $620 \mathrm{~nm}$ against the reagent blank.

In both the methods, the standard calibration curve was prepared or regression equation derived to calculate the amount of analyte drug in unknown samples.
Procedure for the Dosage Forms

Twenty tablets were weighed and groun into a fine powder using a pestle and mortar. A accurately weighed portion of the powder equivalent to $30 \mathrm{mg}$ LMT was transferred into a $100 \mathrm{ml}$ calibrated flask, $50 \mathrm{ml}$ of $0.1 \mathrm{M} \mathrm{H}_{2} \mathrm{SO}_{4}$ was added and the flask was shaken for $20 \mathrm{~min}$. The volume was made upto mark with $0.1 \mathrm{M} \mathrm{H}_{2} \mathrm{SO}_{4}$. After 5 min, the solution was filtered through Whatman No 42 filter paper. First $10 \mathrm{ml}$ portion of the filter was discarded and a suitable aliquot was diluted to get a working concentration of $30 \mu \mathrm{g} \mathrm{mL}^{-1}$ and used for assay by method A. The ion-pair complex of this tablet LMT-BCG $\left(10 \mu \mathrm{g} \mathrm{mL}^{-1}\right)$ was prepared for assay by applying the procedure described in method B.

\section{Results and Discussio}

\section{Spectral Characteristics}

Absorption spectrum of the yellow colore LMT-BCG ion-pair complex is shown in Fig. which has a maximum absorbance $\left(\lambda_{\max }\right)$ at 410 $\mathrm{nm}$. This drug dye ion-pair complex was broken in ethanolic base to yield the base form of the blue dye which had maximum absorbance at $620 \mathrm{~nm}$.

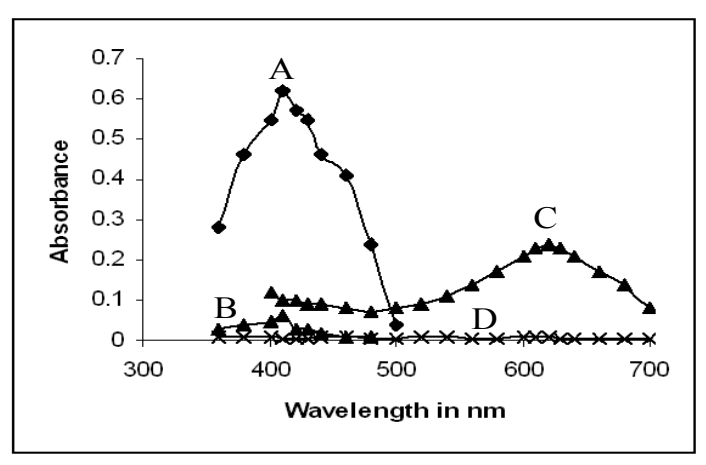

Fig. 1. Absorption spectra of A: ion-pair complex (9.5 $\mu \mathrm{g} \mathrm{mL}^{-1}$ LMT); B: blank in method A, C: base form of dye $\left(1.5 \mu \mathrm{g} \mathrm{mL}^{-1} \mathrm{LMT}\right)$ and $\mathrm{D}$ : blank in method B. In both the cases, the blanks had negligible absorbance. 


\section{Reaction Mechanisms}

Anionic dyes such as BCG forms ion-pair complex with positively charged drugs. The drug-dye stoichiometric ratio as calculated by the Job's continuous variations method [28] is found to be $1: 1$. Each drug-dye complex molecule, with two oppositely charged ions, behaves as a single unit held together by an electrostatic force of attraction (Scheme 1)<smiles>CC(C)N=C(N)[C@H](C)N</smiles>

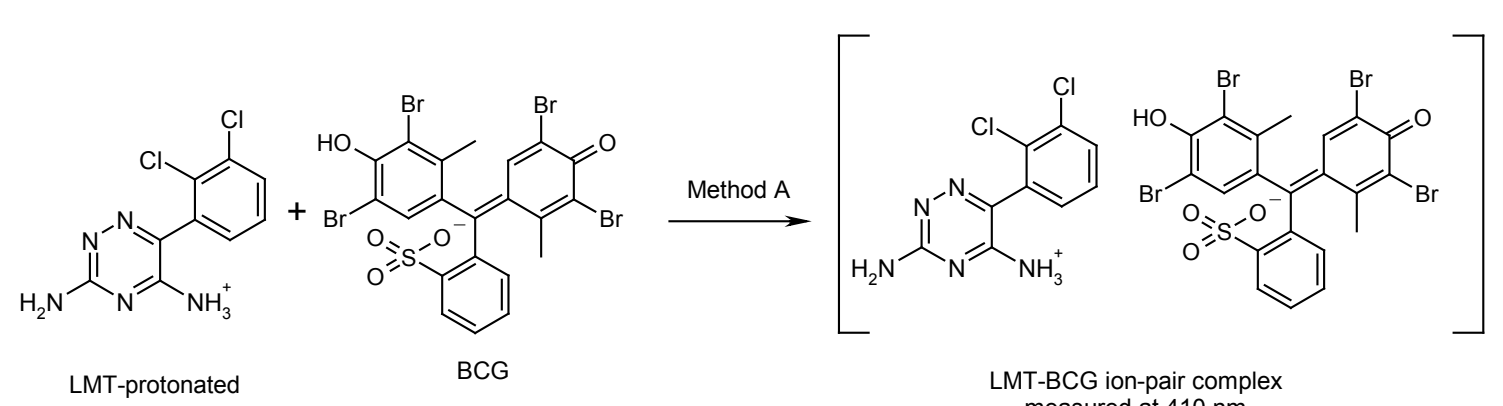

Scheme 1. Reaction pathway for method A.

In alcoholic alkaline medium, this ion-pair complex gets disturbed and it breaks to form a blue colored basic dye and the drug. The mechanism of this breaking is shown in scheme 2 .

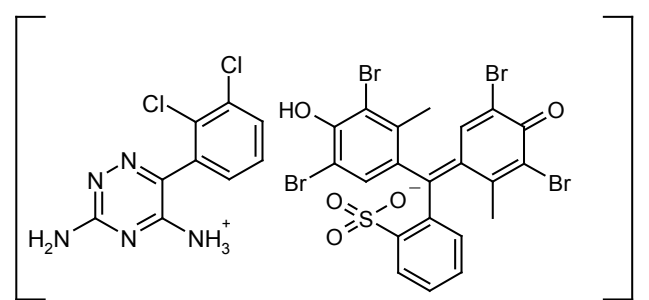

LMT-BCG ion-pair complex

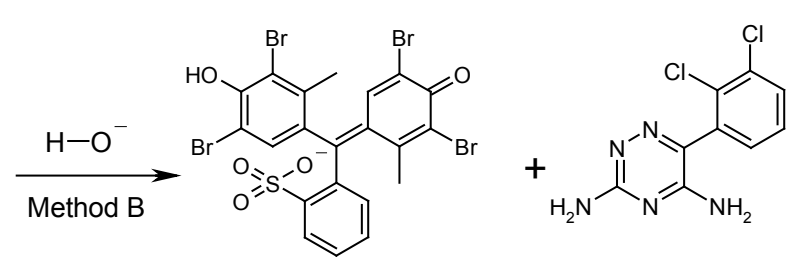
Blue colour of the basic form of
dye measured at $620 \mathrm{~nm}$
Scheme 2. Reaction pathway for method B.

\section{Optimisation of Variables and Method Development}

A number of preliminary experiments established optimum conditions necessary for rapid and quantitative formation of colored ion-pair complex to achieve the maximum stability and sensitivity.
Optimum condition was fixed by varying one parameter at a time while keeping other parameters constant and observing its effect on the absorbanmethod B.

\section{Method A}

\section{Effect of $\mathrm{pH}$}

In order to establish the optimum $\mathrm{pH}$ range, $2 \mathrm{ml}$ of LMT solution in $0.1 \mathrm{M} \mathrm{H}_{2} \mathrm{SO}_{4}$ and $3 \mathrm{ml} 0.1$ $\mathrm{M} \mathrm{H}_{2} \mathrm{SO}_{4}$ were taken and diluted with $5,10,15$ 20 and $25 \mathrm{ml}$ of water. Five $\mathrm{ml}$ of the dye solution was added after the addition of $4 \mathrm{ml}$ of $1 \mathrm{M} \mathrm{NaO}$ $\mathrm{Ac}$ and $5 \mathrm{ml}$ buffer of $\mathrm{pH} 5.02$. The effective $\mathrm{pH}$ value of above resulting aqueous solutions was value of above resulting aqueous solutions was
$5.02 \pm 0.01$. Fig. 2 shows that at $20 \mathrm{ml}$ of water, the absorbance of the ion-pair complex was maximum and the respective blank had shown negligible absorbance. The $\mathrm{pH}$ of the aqueous phase was constant at $5.02 \pm 0.01$ for water volumes ranging from $5-25 \mathrm{ml}$, at a volume of $20 \mathrm{ml}$ water, blank had a lower absorbance. At water volumes greate than $20 \mathrm{ml}$, the sensitivity was less. It was also found that a ratio of $\sim 4: 1$ of aqueous to organic phases was required for the efficient extraction of the colored species. Hence, an aqueous phase of $39 \mathrm{ml}$ which includes $20 \mathrm{ml}$ of $\mathrm{H}_{2} \mathrm{O}$ was used in all subsequent work

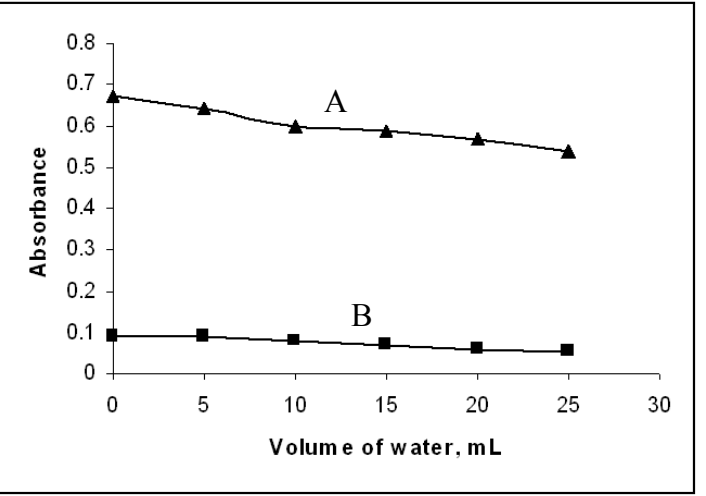

Fig. 2. Effect of water on the absorbance of A: ionpair complex $\left(9.0 \mu \mathrm{g} \mathrm{mL}^{-1} \mathrm{LMT}\right)$ and B: blank.
Effect of sodium acetate, BCG and buffer solution

Various amounts of $\mathrm{NaOAc}$ were added to the acidic solution of lamotrigine to bring the $\mathrm{pH}$ to the optimum value and measurements were carried out as recommended. Maximum absorbance for sample and negligible absorbance for blank was observed when the volume of $\mathrm{NaOAc}$ was $4 \mathrm{~mL}(1 \mathrm{M})$ in a total volume of $39 \mathrm{ml}$. The effect of BCG concentration was investigated by varying the volume of dye solution, and using a fixed amount of drug. The complex formation and its extraction were unaffected in the range of 3.0 to $8.0 \mathrm{ml}$ of $0.4 \% \mathrm{BCG}$ solution. Hence, $5 \mathrm{ml}$ of $0.4 \%$ BCG solution was fixed in a total volume of $39 \mathrm{ml}$ of aqueous phase.

Various amounts of buffer solution were used in the investigation to establish its effect on absorbance. There was almost no influence on the absorbance up to $10 \mathrm{ml}$, but an amount less than $4 \mathrm{ml}$ resulted in unsatisfactory separation of the organic phase during the extraction. So, $5 \mathrm{ml}$ of buffer was used through out the investigation.

\section{Reaction time}

After the addition of dye, the effect of standing time was studied in the time range 5-30 min before extraction. After a contact time of 5 min, measured absorbance of the complex after extraction into dichloromethane, showed almost constant absorbance values from 5-30 min. So a contact time of 5 min was adequate to form the complex.

\section{Effect of shaking time}

Shaking times ranging from 30 to $60 \mathrm{sec}$ produced no change in absorbance, by maintaining all other parameters constant. So a $30 \mathrm{sec}$ shaking time was fixed.

\section{Selecting of the Extracting Solvents}

The effect of the extracting solvent on the ion-pair complex was examined. Dichloromethane was preferred to other solvents (carbon tetrachlo- 
ride, benzene, cyclohexane, hexane, chloroform, 1, 2-dichloroethane and ether) because of its slightly higher efficiency on color intensity, selective extraction of the LMT-BCG complex from the aqueous phase and obtained highest absorbance with dichloromethane.

\section{Effect of number of extractions}

Under optimum conditions, the drug-dye complex in the aqueous phase was extracted with three $10 \mathrm{ml}$ portions of DCM and absorbance was measured each time. After the second extraction, The absorbance of the organic layer was negligibly small. Hence, a single extraction with 10 DCM was selected for the extraction because of complete recovery of the complex.

Equilibration time and stability of the coloured complexes

The organic and aqueous phases were clearly separated in less than $1 \mathrm{~min}$. The drug-dye ion-pair complex was stable for more than $15 \mathrm{~h}$ at laboratory temperatute $\left(30 \pm 2^{\circ} \mathrm{C}\right)$

\section{Effect of order of addition of reactants}

The sequence of order of addition of the reactants prior to extraction had small change in the absorbance values. So the order of addition of reactants should be in the described manner.

\section{Composition of Ion-pair Complexes}

The composition of the ion-pair complex was established by Job's method of continuous variations [28] using equimolar concentrations of the drug and the dye $\left(1.955 \times 10^{-4} \mathrm{M}\right)$. The results indicated that 1:1 (drug:dye) ion-pair is formed through the electrostatic attraction between the positive protonated drug and the anion of dye. Six solutions containing LMT and BCG in various molar ratios, with a total volume of $5 \mathrm{ml}$, in addition to $20 \mathrm{ml} \mathrm{H} \mathrm{H}_{2}, 4 \mathrm{ml}$ of $1 \mathrm{M} \mathrm{NaOAc}$ and $5 \mathrm{ml}$ buffer solution were prepared. The extraction was performed using $10 \mathrm{ml}$ of dichloromethane and

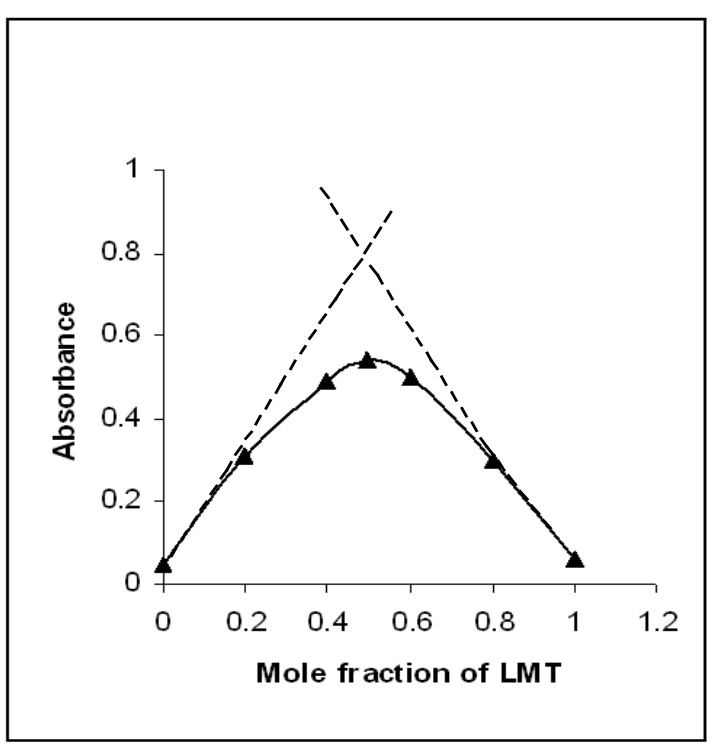
Fig. 3. Job's method of continuous variations plot for at $410 \mathrm{~nm}$

gave a maximum at a molar ratio of $\mathrm{Xmax}=0.5$ which indicated the formatiuon of a 1:1 LMT:BCG complex. The conditional stability constant $\left(\mathrm{K}_{\mathrm{f}}\right)$ of the ion-association complex was calculated from the continuous variation data using the following equation [29]:

$$
K_{f}=\frac{A / A_{m}}{\left[1-A / A_{m}\right]^{n+2} C_{M}(n)^{n}}
$$

where $\mathrm{A}$ and $\mathrm{Am}$ are the observed maximum absorbance and the absorbance value when all the drug present is associated, respectively. $\mathrm{C}_{\mathrm{M}}$ is the mole concentration of drug at the maximum absorbance and $\mathrm{n}$ is the stoichiometry which BCG on ion associates with drug. The $\log \mathrm{K}_{\mathrm{f}}$ value was Method B

Studies on the effect of alkali concentration required to break the complex into its components revealed that $1 \mathrm{~mL}$ of $1 \%$ alcoholic $\mathrm{KOH}$ with a standing time of 5 min was sufficient to yield ma- ximum absorbance at $620 \mathrm{~nm}$. The stability of the resulted blue coloured dye was stable for more than $20 \mathrm{~h}$ at laboratory temperatute $\left(30 \pm 2^{\circ} \mathrm{C}\right)$

\section{Method Validation}

\section{Linearity, sensitivity, limits of detection and quantification}

Calibration graphs were constructed from ten points covering the concentration ranges $1.5-15 \mu \mathrm{g}$ $\mathrm{mL}^{-1}$ and $0.5-5.0 \mu \mathrm{g} \mathrm{mL}^{-1}$ for method A and method B, respectively. Regression analysis of the Beer' law data indicated a linear relationship between absorbance and concentration,

Table 1. Sensitivity and regression parameters

\begin{tabular}{|c|c|c|}
\hline Parameter & Method A & Method B \\
\hline$\lambda_{\max }, \mathrm{nm}$ & $4^{10}$ & $6^{20}$ \\
\hline Color stability & $>24 \mathrm{~h}$ & $>20 \mathrm{~h}$ \\
\hline Linear range, $\mu \mathrm{g} \mathrm{mL}^{-1}$ & $1.5-15$ & $0.5-5.0$ \\
\hline Molar absorptivity $(\varepsilon), 1 \mathrm{~mol}^{-1} \mathrm{~cm}_{-} 1$ & $1.6932 \times 10^{4}$ & $3.748 \times 10^{4}$ \\
\hline Sandell sensitivity*, $\mu \mathrm{g} \mathrm{cm}^{-2}$ & 0.0151 & 0.0068 \\
\hline Limit of detection (LOD), $\mu \mathrm{g} \mathrm{ml}^{-1}$ & 0.43 & 0.19 \\
\hline Limit of quantification (LOQ), $\mu \mathrm{g} \mathrm{ml}^{-1}$ & 1.30 & 0.59 \\
\hline \multicolumn{3}{|l|}{ Regression equation, $\mathrm{Y}^{* *}$} \\
\hline Intercept (a) & -0.0007 & 0.0007 \\
\hline Slope (b) & 0.0661 & 0.1463 \\
\hline Standard deviation of a $\left(\mathrm{S}_{\mathrm{a}}\right)$ & 0.0998 & 0.0998 \\
\hline$\pm \mathrm{tS}_{\mathrm{a}} / \sqrt{\mathrm{n}}$ & 0.124 & 0.124 \\
\hline Standard deviation of $b\left(S_{b}\right)$ & 0.0073 & 0.022 \\
\hline$\pm \mathrm{tS}_{\mathrm{b}} / \sqrt{\mathrm{n}}$ & 0.0091 & 0.027 \\
\hline Variance $\left(\mathrm{S}_{\mathrm{a}} 2\right)$ & 0.0096 & 0.0096 \\
\hline Regression coefficient (r) & 0.9993 & 0.9996 \\
\hline
\end{tabular}

"Limit of determination as the weight in $\mu \mathrm{g}$ per $\mathrm{ml}$ of solution, which corresponds to an $\mathrm{ab}$ sorbance of $\mathrm{A}=0.001$ measured in a cuvette of cross-sectional area $1 \mathrm{~cm}^{2}$ and $1=1 \mathrm{~cm}$ ${ }^{* *} \mathrm{Y}=\mathrm{a}+\mathrm{bX}$, Where $\mathrm{Y}$ is the absorbance, $\mathrm{X}$ is concentration in $\mu \mathrm{g} \mathrm{mL} \mathrm{L}^{-1}$, $\mathrm{a}$ is intercept, $\mathrm{b}$ is slope, $\pm \mathrm{tS} / \mathrm{V}_{\mathrm{n}}$ $=$ confidence limit for intercept, $\pm \mathrm{tS}_{\mathrm{b}} / \mathrm{V}_{\mathrm{n}}=$ confidence limit for slope. 
which is corroborated by high values (close to $\varepsilon$ and low values of Sandell sensitivity and LOD unity) of the correlation coefficients. A plot of indicate the high sensitivity of the proposed me$\log$ absorbance and $\log$ concentration, yielded thods.

straight lines with slope equal to 0.996 and 1.009 for method $\mathrm{A}$ and method $\mathrm{B}$, respectively, further for establishing the hin relation between the two variables. The calculated nolar absorptivity and Sandell sensitivity [30] values are summarized in Table 1. The limits of detection (LOD) and quantification (LOQ), calculated according to the ICH guidelines [31] using the formulae:

$\mathrm{LOD}=3.3 \mathrm{~S} / \mathrm{b}$ and $\mathrm{LOQ}=10 \mathrm{~S} / \mathrm{b}$, (where $\mathrm{S}$ is the standard deviation of blank absorbance values, and $\mathrm{b}$ is the slope of the calibration plot) are also summarized in Table 1. The high values of

Table 2. Evaluation of intra-day and inter-day accuracy and precision

\begin{tabular}{|c|c|c|c|c|c|c|c|}
\hline \multirow{2}{*}{ Method } & \multirow{2}{*}{$\begin{array}{l}\text { LMT taken, } \\
\mu \mathrm{g} \mathrm{mL}-1\end{array}$} & \multicolumn{3}{|c|}{$\begin{array}{l}\text { Intra-day accuracy and precision } \\
\qquad(\mathrm{n}=7)\end{array}$} & \multicolumn{3}{|c|}{$\begin{array}{l}\text { Inter-day accuracy and precision } \\
\qquad(\mathrm{n}=5)\end{array}$} \\
\hline & & $\begin{array}{l}\text { LMT found } \\
\pm \mathrm{CL}, \mu \mathrm{g} \mathrm{mL}-1\end{array}$ & $\% \mathrm{RE}$ & $\%$ RSD & $\begin{array}{l}\text { LMT found } \pm \text { CL, } \\
\qquad \mu \mathrm{g} \mathrm{mL}^{-1}\end{array}$ & $\% \mathrm{RE}$ & $\%$ RSD \\
\hline \multirow{3}{*}{ A } & 6.0 & $5.90 \pm 0.08$ & 1.67 & 1.52 & $5.96 \pm 0.14$ & 0.67 & 1.82 \\
\hline & 9.0 & $8.92 \pm 0.11$ & 0.89 & 1.36 & $8.99 \pm 0.11$ & 0.11 & 1.02 \\
\hline & 12.0 & $12.01 \pm 0.22$ & 0.08 & 1.96 & $11.98 \pm 0.30$ & 0.17 & 2.01 \\
\hline \multirow{3}{*}{ B } & 1.0 & $1.01 \pm 0.01$ & 1.00 & 0.884 & $1.02 \pm 0.02$ & 2.00 & 1.16 \\
\hline & 3.0 & $3.04 \pm 0.02$ & 1.33 & 0.603 & $3.02 \pm 0.04$ & 0.67 & 0.2 \\
\hline & 5.0 & $5.01 \pm 0.02$ & 0.20 & 0.450 & $4.98 \pm 0.05$ & 0.40 & $0.0^{2}$ \\
\hline
\end{tabular}

\%RE. Percent relative error, \%RSD. relative standard deviation and CL. Confidence limits were calculated from: $\mathrm{CL}= \pm \mathrm{tS} / \sqrt{\mathrm{n}}$. (The tabulated value of $\mathrm{t}$ is 2.45 and 2.77 for six and four degrees of freedom respectively, at the $95 \%$ confidence level; $\mathrm{S}=$ standard deviation and $\mathrm{n}=$ number of measurements).

\section{The percentage relative standard devia- Selectivity} tion (\%RD) values were $<2 \%$ (intra-day) and $\leq 2.01 \%$ (inter-day) indicating high precision of the methods. The accuracy of the precison of the methods The determined by the percent mean deviation from known concentration, bias $\%=[$ (Concentration found - known concentration) x $100 /$ known concentration]. Bias was calculated at each concentration and these results are also presented in Table 2. Percent relative error ( $\% \mathrm{RE})$ values $\leq 2.0$ $\%$ demonstrate the high accuracy of the proposed methods.

A systematic study was performed to determine the effect of matrix by analyzing the placebo blank and syntetic mixture containing LMT. A placebo blat of the compositaning LMT. A placebo blank of the composition: starch (10 $\mathrm{mg})$, acacia (15 mg), hydroxyl cellulose ( $10 \mathrm{mg})$ sodium citrate $(10 \mathrm{mg})$, talc $(20 \mathrm{mg})$, magnesium stearate $(15 \mathrm{mg})$ and sodium alginate $(10 \mathrm{mg})$ was made and its solution was prepared as described under 'tablets', and then subjected to analysis. The absorbance of the placebo solution in each case was almost equal to the absorbance of the blank which revealed no interference. To asses the role of the inactive ingredients on the assay of LMT, a synthetic mixture was separatyy prepard by adding $10 \mathrm{mg}$ of LMT to the placebo mentio-

ned above. The drug was extracted and solution prepared as described under the general procedure for tablets. The solution after appropriate dilution were analysed following the recommended tion whe The sol procedures. 12 a 140 $\mathrm{mL}^{-1}$ (method A) and $4.0 \mu \mathrm{g} \mathrm{mL}-1$ (method B) were nearly the same as those obtained for pure LMT solutions of identical concentrations. This unequivocally demonstrated the non-interference of the inactive ingredients in the assay of LMT. Further, the slopes of the calibration plots prepared from the synthetic mixture solutions were about the same as those prepared from pure drug solutions. in both instances were in the range $0.88-1.65 \%$ indicating acceptable ruggedness. The results are presented in Table 3.

Table 3. Method robustness and ruggedness expressed as intermediate precision (\% RSD)

\begin{tabular}{|c|c|c|c|c|c|}
\hline \multirow{3}{*}{ Method } & \multirow{3}{*}{$\begin{array}{c}\text { LMT } \\
\text { taken, } \\
\mu \mathrm{g} \\
\mathrm{mL}^{-1}\end{array}$} & \multirow{2}{*}{\multicolumn{2}{|c|}{$\begin{array}{c}\text { Robustness } \\
\text { Parameters altered }\end{array}$}} & \multicolumn{2}{|c|}{ Ruggedness } \\
\hline & & & & \multirow{2}{*}{$\begin{array}{l}\text { Inter-analysts } \\
\text { (\%RSD), } \\
(\mathrm{n}=4)\end{array}$} & \multirow{2}{*}{$\begin{array}{l}\text { Inter-instruments } \\
\quad \% \text { RSD }), \\
(\mathrm{n}=4)\end{array}$} \\
\hline & & $\begin{array}{l}\text { Volume of } \mathrm{H} 2 \mathrm{O} / \\
\text { Ethanolic } \mathrm{KOH}^{*}\end{array}$ & $\begin{array}{l}\text { Reaction/Breaking } \\
\text { time }^{\Psi}\end{array}$ & & \\
\hline A & 6.0 & 1.02 & 1.23 & 0.88 & 1.65 \\
\hline B & 3.0 & 0.96 & 1.53 & 0.99 & 1.58 \\
\hline
\end{tabular}

"In method $\mathrm{A}$, the volume of $\mathrm{H}_{2} \mathrm{O}$ was 17,20 and $23 \mathrm{~mL}$, and in method B the volumes of ethanolic $\mathrm{KOH}$ added were $0.8,1.0$ and $1.20 \mathrm{~mL}$.

${ }^{\Psi} \mathrm{In}$ method $\mathrm{A}$, the reaction times were 3, 5 and $7 \mathrm{~min}$ and in method B breaking times were 3, 5 and 7 $\min$.

\section{Application}

The proposed methods were applied for the quantification of LMT in commercial tablets. The results were compared with these obtained using a published method [20]. The method consisted of the measurement of the absorbance of the tablet extract in $0.1 \mathrm{M} \mathrm{NaOH}$ at $305 \mathrm{~nm}$. Statistical analysis of the results did not detect any significant difference between the performance of the proposed methods and reference method with respect to accuracy and precision as revealed by the Student's t-value and variance ratio F-value [32] The results of assay are given in Table 4 
Table 4. Results of analysis of tablets by the proposed methods and statistical comparison of the results with the reference method

\begin{tabular}{|c|c|c|c|c|}
\hline \multirow{2}{*}{$\begin{array}{l}\text { Tablet brand } \\
\text { name }{ }^{\psi}\end{array}$} & \multirow{2}{*}{$\begin{array}{l}\text { Nominal amount, } \\
\text { (mg/tablet) }\end{array}$} & \multicolumn{3}{|c|}{ Found* (Percent of label claim \pm SD) } \\
\hline & & Reference method & Method A & Method B \\
\hline Lamosyn-100 ${ }^{\mathrm{a}}$ & 100 & $98.56 \pm 0.76$ & $\begin{array}{c}98.14 \pm 1.12 \\
\mathrm{t}=0.71 \\
\mathrm{~F}=2.17\end{array}$ & $\begin{array}{c}99.04 \pm 1.06 \\
\mathrm{t}=0.83 \\
\mathrm{~F}=1.95\end{array}$ \\
\hline Lamosyn-25a & 25 & $101.3 \pm 0.62$ & $\begin{array}{c}100.6 \pm 0.86 \\
t=1.49 \\
F=1.92\end{array}$ & $\begin{array}{c}101.1 \pm 0.90 \\
\mathrm{t}=0.42 \\
\mathrm{~F}=2.11\end{array}$ \\
\hline Lametec-50 DT ${ }^{\mathrm{b}}$ & 50 & $102.5 \pm 0.86$ & $\begin{array}{c}101.2 \pm 1.05 \\
\mathrm{t}=2.15 \\
\mathrm{~F}=1.49\end{array}$ & $\begin{array}{c}101.8 \pm 0.72 \\
t=1.40 \\
F=1.43\end{array}$ \\
\hline
\end{tabular}

Mean value of 5 determinations.

(Tabulated t-value at the $95 \%$ confidence level and for four degrees of freedom is 2.77 ).

(Tabulated F-value at the $95 \%$ confidence level and for four degrees of freedom is 6.39).

Marketed by: ${ }^{a}$ Sun pharmaceuticals.

${ }^{\mathrm{b}} \mathrm{Cipla}$ India Ltd, Mumbai.

\section{Recovery stud}

To further assess the accuracy of the methods, recovery experiments were performed by applying the standard-addition technique. The recovery was assessed by determining the agreement between the measured standard concentration and added known concentration to the sample. The test was done by spiking the pre-analysed tablet powder with pure LMT at three different le- vels $(50,100$ and $150 \%$ of the content present in the tablet powder (taken) and the total was found by the proposed methods. Each test was repeated three times. In all the cases, the recovery percentage values ranged between 99.22 and $104.3 \%$ with standard deviation in the range $0.85-1.25$ $\%$. Closeness of the results to $100 \%$ showed the fairly good accuracy of the methods. The results are shown in Table 5 .

Table 5. Results of recovery study via standard-addition method

\begin{tabular}{|c|c|c|c|c|c|c|c|c|}
\hline \multirow[b]{2}{*}{ Tablet studied } & \multicolumn{4}{|c|}{ Method A } & \multicolumn{4}{|c|}{ Method B } \\
\hline & $\begin{array}{l}\text { LMT in tablet, } \\
\mu \mathrm{g} \text { mL-1 }\end{array}$ & $\begin{array}{c}\text { Pure LMT } \\
\text { added, } \mu \mathrm{g} \\
\mathrm{mL}^{-1}\end{array}$ & $\begin{array}{l}\text { Total found, } \\
\mu \mathrm{g} \mathrm{mL} \mathrm{L}^{-1}\end{array}$ & $\begin{array}{c}\text { Pure LMT } \\
\text { recovered } \\
\text { (Percent_SD*) }\end{array}$ & $\begin{array}{l}\text { LMT in tablet, } \\
\mu \mathrm{g} \mathrm{mL} \mathrm{L}^{-1}\end{array}$ & $\begin{array}{c}\text { Pure LMT } \\
\text { added, } \mu \mathrm{g} \\
\mathrm{mL}^{-1} \\
\end{array}$ & $\begin{array}{l}\text { Total found, } \\
\mu \mathrm{g} \mathrm{mL}-1\end{array}$ & $\begin{array}{c}\text { Pure LMT } \\
\text { recovered } \\
\left.\text { (Percent } \pm S D^{*}\right)\end{array}$ \\
\hline \multirow{3}{*}{ Lamosyn-100 } & 4.91 & 2.5 & 7.44 & $101.2 \pm 0.96$ & 1.98 & 1.0 & 2.98 & $100.2 \pm 1.06$ \\
\hline & 4.9 & 5. & 9.8 & $99.22 \pm 0.85$ & & 2.0 & 4.04 & $103.2 \pm 1.25$ \\
\hline & 4.91 & 7.5 & 12.73 & $104.3 \pm 1.25$ & 1.98 & 3.0 & 4.96 & $99.23 \pm 0.98$ \\
\hline
\end{tabular}

"Mean value of three determinations.

\section{Conclusions}

In the present study, the maximum color development of LMT-BCG ion-pair complex $(\operatorname{method} \mathrm{A})$ and basic dye (method B) was instantaneous. No heating or standing was needed. These methods do not involve procedural steps, do not take more operator time and expertise like HPLC and other methods. In terms of simplici ty, rapidity, sensitivity and expense, the method could be considered superior in comparison with the previously reported methods, especially with those based on chromatography [3-15]. The reagents utilized in the proposed methods are cheaper, readily available and the procedures do not involve any critical reaction conditions or tedious sample preparation. The method is unaffer sample prepartion. The meth is unected by slight variations in experimental conditions such as time, reagent concentration or temperature. The methods are highly sensitive compared to the only spectrophotometric method [14]. Since there was no interference from the tablet excipients, the methods are highly selective in comparison with the chloranilic acid and method based on chargetransfer complexation method [14].

The proposed methods gave results with good accuracy to permit determination of low concentracy to concentica applicability of the described procedure for routine quality control is well established by the assay of LMT in pure form, as well as in pharmaceutica preparations

\section{Aknowledgement}

Authors thank M/S. Cipla India Ltd, for gifting pure lamotrigine, two of the authors (NRP \& KBV) are gratefully thanks the University of Mysore, Mysore, permission and facilities and on of the authors (NRP) gratefully acknowledges the UGC, New Delhi, for providing Meritorious Research Fellowship.

\section{References}

[1] A.G. Gilman, J.G. Hardman, L.E. Limbird, "Goodman and Gilman's the Pharmacological Basis of Therapeutics " [2] C. Seraw Hil, New York, U.S.A. (2001) pp. 339. [2] C. Sean, Sweetman, Martindale. The Complete Drug Reference 34th ed. Pharmaceutical Press, London. (2005) pp [3]

[3] M. Cociglio, R. Alric, O. Bouvier, J. Chromatogr. Biomed Appl. 110: 1-2, J.Chromatogr. 572 (1991) 269. H.L. Lensmeyer, B.E. Gidal, D A. Wiebe, Ther. Drug Mo-

[5] P. Angelis-Stoforidis, D.J. Morgan, T J. O'Brien, F.J.E.

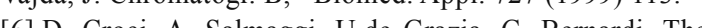
Drug Monit 23 (2001) 665 . [7] M.M. Cas (200) 665 .

政, A.M. Almeida, A.C. Falcao, T.A. F.G.Lopez, J. Chromatogr. B, Biomed. Appl. 755 (2001) 119.

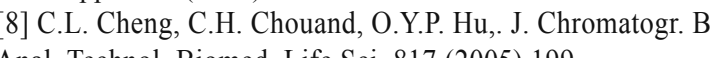

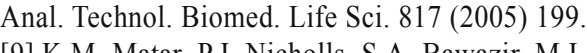
[9] K.M. Matar, P.J. Nicholls, S.A. Bawazir, M.I. Al-Hassan,

[10] D. Londero, P. Lo Greco, J. Chromatogr. B. Biomed. Sci.

[11] K.M. Patil, S.L. Bodhankar, J. Chromatogr. B, 823 (2005) 152

Clin. Biochem. 35 (1997) 755 . 
4541.

[15] G-S. Elizabeth, S. Giannoutsos, D.R. Lower, M.A. Virji, M.D. Krasowski, J. Chromatogr. Sci. 45 (2007) 9616.

[16] Z.K. Shihabi, K.S. Oles, J. Chromatogr. B, Biomed Appl. $683(1996) 119$.

[17] R. Theurillat, M. Kuhn, W. Thormann, J. Chromatogr. A. 979 (2002) 353.

[18] R.A. Biddlecombe, K.L. Dean, C.D. Smith, S.C. Jeal,. J. Pharm. Biomed. Anal. 8 (1990) 691

[19] J.M. Sailstad. J.W.A. Findlay, Ther. Drug. Monit., 13 (1991) 433.

[20] R.S. Talekar, A.S.Dhake, D.B. Sonaje, V.K. Mourya, Ind. J. Pharm. Sci. 62 (2000) 51.

[21] D-R. Olga, M.E Calvo, M. Acros-Martinez, J.. Sensors. 8 (2008) 4201; DOI:10.3390/s807420

[22] N. Rahman, S.N. Hejaz-Azmi, J. Pharm. Biomed. Anal. $24(2000) 33$.

[23] N. Silva, E.E.S. Schapoval, J. Pharm. Biomed. Anal. 29 (2002) 749.

[24] T. Perez-Ruiz, C. Martinez-Lozano, V. Tomás, A. Sanz, E. Sauquillo, J. Pharm. Biomed. Anal. 26 (2001) 609.

[25] K. Basavaiah, V.S. Charan, LL Farmaco. 57 (2002) 9.

[27] H. Fagson, H. Yawya-saeb, A. Fawzy, Int, J. Ph 32.7 (1981) 343 . H. Ya

[28] A.S. Douglas, M.W. Donald. "Principels of Instrumental Analysis," Holt, Rinhart and Winston, New York, 1971.pp. 104.

[29] N. Erk. Anal. Lett. 36 (2003) 1183.

[30] H. Zavis, D. Ludvik, K. Milan, S. Ladislaw, V. Frantisck, Handbook of Organic Reagents in Inorganic Analysis. Translated by Stanislav, K, Dr. Chalmers (The Series and Translation Editor: University of Aberdem, Ellis Horwood Limited, Chichester, A Division of John Wiley \& Sons IC, New York, London, Sydney, Toronto. 1976. pp.364.

[31] International Conference on Hormonisation of Technical Requirements for Registration of Pharmaceuticals for Humal Use, ICH Harmonised Tripartite Guideline, Validation of Analytical Procedures: Text and Methodology Q2(R 1).Complementary Guideline on Methodology dated 06 November 1996, incorporated in November 2005, London.

[32] J. Inczedy, T. Lengyel, A.M. Ure,. IUPAC Compendium of Analytical Nomenclature : 1998. Definitive Rules, Blackwell Science Inc., Boston.

\section{COMPLEXES OF 4-CHLOROPHENOXYACETATES OF ND(III), GD(III) AND HO(III)}

W.Ferenc ${ }^{*}$, M.Bernat ${ }^{l}$, J.Sarzyński ${ }^{2}$ and H.Gluchowska 'Faculty of Chemistry, Maria Curie-Sklodowska University, PL 20-031 Lublin, Poland

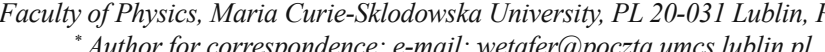

Abstract: The complexes of 4-chlorophenoxyacetates of Nd(III), Gd(III) and Ho(III) have bee synthesized as polycrystalline hydrated solids, and characterized by elemental analysis, spectroscopy, magnetic studies and also by X-ray diffraction and thermogravimetric measurements. The analysed complexes have the following colours: violet for $\mathrm{Nd}(\mathrm{III})$, white for $\mathrm{Gd}(\mathrm{III})$ and cream for $\mathrm{Ho}$ (III) compounds. The carboxylate groups bind as bidentate chelating (Ho) or bridging ligands $(\mathrm{Nd}, \mathrm{Gd})$. On heating to $1173 \mathrm{~K}$ in air the complexes decompose in severa steps. At first, they dehydrate in one step to form anhydrous salts, that next decompose to the oxides of respective metals. The gaseous products of their thermal decomposition in nitrogen were also dective and the magnetic susceptibilites were mesured over the temperat rophenoxyacetates of $\mathrm{Nd}(\mathrm{III}), \mathrm{Gd}(\mathrm{III})$ and $\mathrm{Ho}(\mathrm{HI})$ are high-spin compexes with weak ligand fields. The solubility value in water at $293 \mathrm{~K}$ for analysed 4-chlorophenoxyacetates is in the order of $10^{-4} \mathrm{~mol} / \mathrm{dm}^{3}$

Keywords: 4-chlorophenoxyacetates, thermal stability, magnetic properties of $\mathrm{Nd}(\mathrm{III}), \mathrm{Ho}(\mathrm{III})$ and $\mathrm{Gd}(\mathrm{III})$.

\section{Introduction}

The carboxylates play an important role in norganic and bioinorganic chemistry. Many metal cations are a component of several vitamins and drugs $[1,2]$. The carboxylates of $\mathrm{d}$ and $4 \mathrm{f}$ and elements may be use as electic modern branches of techiques and technology. They may have also applications as precursors in superconducting ceramic and magnetic field productions and may be used as catalysts, pigments, solvents, food preservatives and plastics produc tions.

Metal carboxylates are applied for the productions of high degree purity of metal oxides and polycarboxylic acids are used for supermolecular with metal ions the molecular polymers containing in their structures, pores and channels owning to them they appear catalytic and adsorption properties. Therefore they may be used for the adsorption of inorganic gases such as: argon, nitrogen and hydrocarbons or small molecules of anothe inorganic compounds. Polycarboxylic acids may also form the molecules with two- and three-dimentional structures, yielding special magnetic and luminescence properties which let them be used in optical and electronic industries [3-10]. 4 -Chlophenoxy id hardly soluble in soluble soluble in water $\left(\mathrm{K}=7,9 \cdot 10^{4}\right)$ and easily soluble in ether and ethanol $[10,11]$. It is used as growth hormone for plants [12]. In some papers the details of its molecular structure was presented [13-15]. Literature survey informs that its complexes with Li(I), Cu(II), Co(II), Mn(II) and 